Робота присвячується аналізу гео-
метрично нелінійних контактних задач
для системи смуг. Особливості пред-
ставленої задачі полягають у досліджен-
ні напружено-деформованого стану двох
смуг, сполучених болтовим кріпленням із
зазором і навантажених рівномірно роз-
поділеним по верхній кромці поперечним
зусиллям. У цій постановці задачі при-
сутні геометрична і структурна нелі-
нійності. Отримано основні закономір-
ності напружено-деформованого стану
елементів силосів

Ключові слова: напружено-деформований стан, силос, метод скінченних елементів, система смуг, реакції в опорах

$\square$

Данная работа посвящается анализу геометрически нелинейных контактных задач для системы полос. Особенности представленной задачи заключаются в исследовании напряженно-деформированного состояния двух полос, соединенных болтовым крепежом с зазором $и$ нагруженных равномерно распределенным по верхней кромке поперечным усилием. В данной постановке задачи присутствуют геометрическая и структурная нелинейности. Получены основные закономерности напряженно-деформированного состояния әлементов силосов

Ключевые слова: напряженно-деформированное состояние, силос, метод конечных әлементов, система полос, реакции в опорах

$\square$

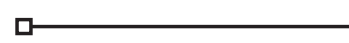

UDC 539.3

DOI: $10.15587 / 1729-4061.2016 .60087$

\section{A NUMERICAL ANALYSIS} OF NON-LINEAR CONTACT TASKS FOR THE SYSTEM OF PLATES WITH A BOLTED CONNECTION AND A CLEARANCE IN THE FIXTURE

O. A troshenko Junior Researcher*

E-mail: atroshenko@tmm-sapr.org

M. T k a c h u k

Doctor of Technical Science, Professor*

E-mail: tma@tmm-sapr.org

O. Us t i ne n k o

$\mathrm{PhD}$, Associate Professor*

E-mail: ustin1964@tmm-sapr.org

O. B o nd a re n k o

$\mathrm{PhD}$ *

E-mail: avbondarenko@yandex.ua

N. Diom in a

$\mathrm{PhD}$, Associate Professor

Department of Mathematics and Physics

Tavria State Agrotechnological University Khmelnytskyi ave., 18, Melitopol, Ukraine, 72312

*Department of the Theory and

Computer-Aided Design of Mechanisms and Machines National Technical University "Kharkiv Polytechnic Institute"

Frunze str., 21, Kharkiv, Ukraine, 61002

\section{Introduction}

Silos that are widely used in modern agriculture have several advantages, such as easy assembling, reliability, low cost, and easy management. Since there is a huge stress exerted upon silos, the stress-strain state (SSS) under the internal pressure of the grain bulk must be taken into account and thoroughly calculated. This entails the use of a particular calculation model for the metal structure elements of the considered silos.

The main structural elements of the silos are usually corrugated panels. Preliminary tightening and bolt fixtures that have clearances connect the panels to vertical stiffeners. As a result, there is a system of plates supported by rods (columns) with bolt fixtures between them. In case of the gap adjustment, there are forces of contact interaction between the cylindrical part of a bolt and inner surfaces of the holes made in the mating panels.

This formulation considers geometrical, structural and physical nonlinearities. Solution of the tasks on the behavior of the studied silo construction allows analyzing it in more detail. The contact of two flat overlapped plates fixed with a bolt was proposed as the initial option of investigation instead of corrugated panels.

Finally, we have devised a contact interaction model of a number of bodies with the preload, friction and contact with a gap. The obtained model was compared to the traditional one, i. e. the silo structure fragment in the form of a solid plate.

The existing problematic issues in the standard methods required setting up goals to improve the existing methods and models for studying the design of such structures. This determined the direction and relevance of the research, as described in the proposed article.

2. Analysis of the published data and formulation of the problem

Traditionally, calculations of thin-walled structures are based on the European standards presented in the "Eurocodes" [2-4]. The analysed works [5, 6] present numerical 
and experimental studies on specimens of panels that are preliminary tightened and connected with a bolt fixture. Such items usually are predominant structural units of metal silos. Another study [7] is devoted to the research on steel silos of a cylindrical shape that use corrugated panels. These structures are under the actual load of bulk materials, however the study did not consider application of bolted connections. Other researchers [8] set a more comprehensive task with regard to both corrugated panels and bolted connections. In general, the above mentioned research suggests quite an extended solution of the problem although without a detailed study of a single bolted connection. The next study [9] analyzed the SSS of bolted connections, but it does not take into consideration the bolted connection with a clearance. Other researchers [10] studied the interdependence of the SSS and the used bolted connections with clearances. Although even with the bolted connection used in the steel silos the connected panel worked on the longitudinal transverse bending.

The suggested study deals with a number of model problems, such as bolted connections with clearances, longitudinal and transverse bending, as well as various arrangements of bolted connections including the pliable washer.

\section{The purpose and objectives of the study}

The purpose of the study is to develop an improved calculation model for the analysis of geometrically nonlinear contact tasks for the system of two plates that have bolted connection and clearances in bolt fixtures and are loaded with a uniformly distributed transverse force along the upper edge. The objectives of the study are as follows:

- to analyze the impact of both geometric and structural nonlinearities;

- to assess the use of bolt fixtures in different configurations and with different friction coefficients in the connections of the plates or a plate with a bolt;

- to analyze and assess the sliding effect for the contacting surfaces of the plates when the system loading varies.

These tasks can be solved on the basis of the model system of overlapped plates connected with a bolt fixture that has a clearance (Fig. 1).

The geometrical parameters of the system are as follows: length $\mathrm{l}=500 \mathrm{~mm}$, width $\mathrm{C}=50 \mathrm{~mm}$, thickness $\mathrm{h}=2 \mathrm{~mm}$, the total length of the connected plates $\mathrm{L}=960 \mathrm{~mm}$, the hole diameter $\mathrm{d} 1=12 \mathrm{~mm}$, and the bolt diameter $\mathrm{D}=10 \mathrm{~mm}$.
Bolted connections have the following configuration: a bolt is inserted through the fixture clearance and through the plate hole and tightened by a nut to a torque that is equal to $T_{K}$. If the tensile force exceeds the friction force, there will be a shear of plates up to the clearance adjustment as the contacting cylindrical surface of the bolt and holes of the plates come into operation.

Loading model is shown in Fig. 2 (construction is in the cut form and symmetric about the plane $\mathrm{xOz}$ ). Plates are rigidly held on the edges. The limitation of the displacement along the $\mathrm{y}$-axis is set along the symmetry plane $\mathrm{xz}$.
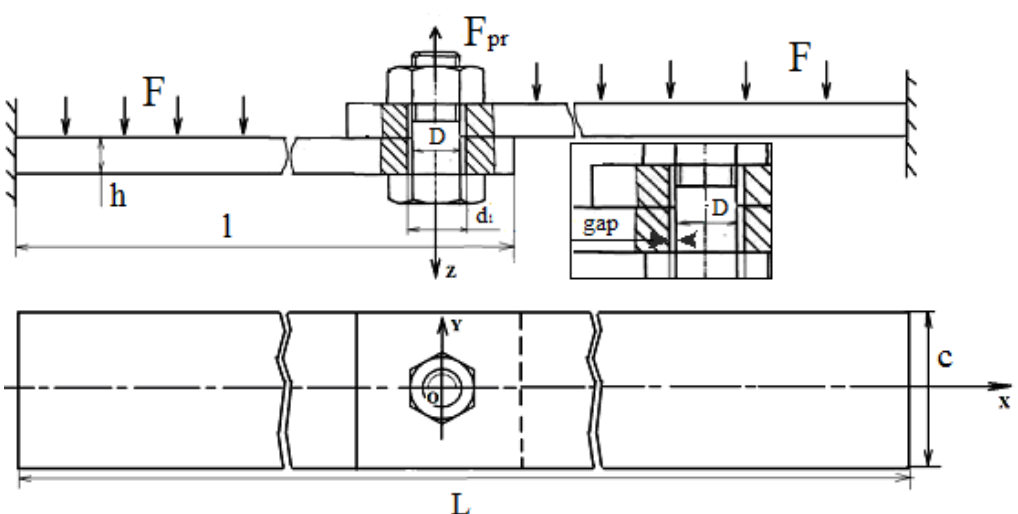

Fig. 1. System of plates with a bolted connection

The limitation of the displacement along the y-axis is set along the symmetry plane xz. Transverse forces distributed along the upper edge are set by the force $\mathrm{F}$ (the system is loaded incrementally from 0 to $450 \mathrm{~N}$ ). The tightening torque is modeled in the form of the tightening force of the bolt $F_{p r}=1000 \mathrm{~N}$. The bolt fixture was modeled in various arrangements, i. e. the contact of plates and a bolt, the contact of a plate and a bolt over two washers and the contact of a plate and a bolt over one washer (Fig. 3, $a-c$ ). The washer is made of compliance material with a low modulus of elasticity (polyethylene) for a more uniform distribution of the cap bolt pressure onto the plate surface.

The study considers options for bolt fixtures with different friction forces in contact, which allows a thorough and more detailed analysis of the problem. Types of contact and coefficients of friction are shown in Table 1.

Table 1 presents options with various configurations of bolted fixtures that are aimed at implementation of the contact interaction. The first, the second and the third options are used for bolted connection of the first type where only the coefficient of friction varies, whereas the fourth and the fifth options belong to the second type of bolted connection that uses two washers and also has a variable friction coefficient, and the sixth one belongs to the third type of connection that uses one washer.

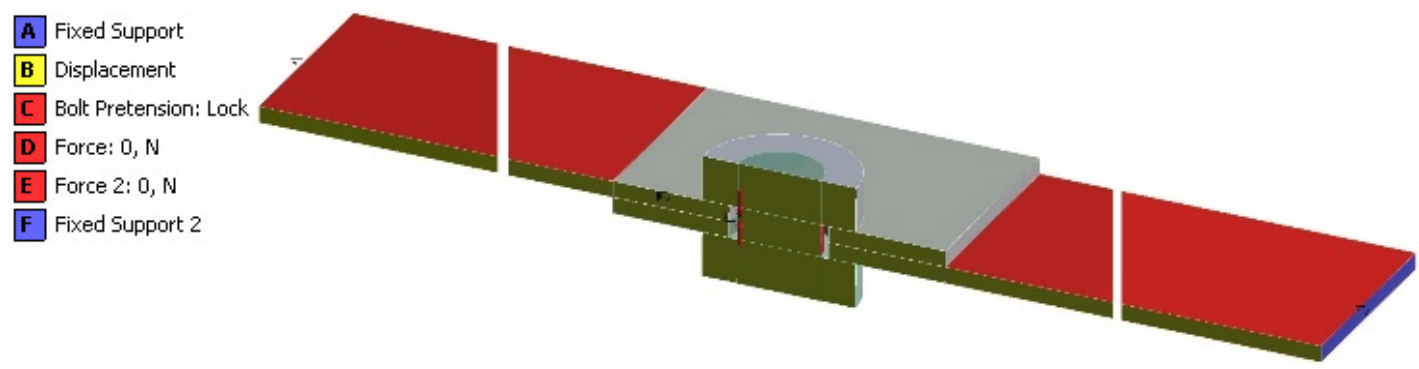

Fig. 2. The analyzed model with boundary conditions 

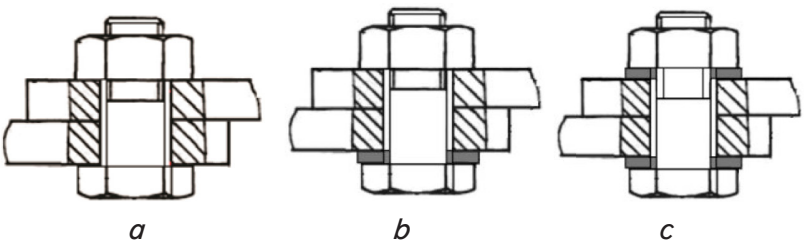

Fig. 3. Bolt fixture: $a-$ the contact of plates and a bolt; $b$ - the contact of a plate and a bolt over two washers; $c$ - the contact of a plate and a bolt over one washer

Table 1

Contact types and friction coefficients

\begin{tabular}{|c|c|c|c|c|c|}
\hline \multirow{2}{*}{$№$} & \multicolumn{5}{|c|}{ Types of contact } \\
\cline { 2 - 6 } & $\begin{array}{c}\text { Friction } \\
\text { plate-plate }\end{array}$ & $\begin{array}{c}\text { Friction } \\
\text { plate-bolt }\end{array}$ & $\frac{\text { Frictionless }}{\text { hole-bolt }}$ & $\begin{array}{c}\frac{\text { Friction }}{\text { plate- }} \\
\text { washer }\end{array}$ & $\begin{array}{c}\text { Bonded } \\
\text { bolt-washer }\end{array}$ \\
\hline 1 & 0.2 & 0.2 & + & - & - \\
\hline 2 & 0.2 & 0.001 & + & - & - \\
\hline 3 & 0.0001 & 0.0001 & + & - & - \\
\hline 4 & 0.2 & - & + & 0.2 & + \\
\hline 5 & 0.2 & - & + & 0.001 & + \\
\hline 6 & 0.2 & - & + & 0.2 & + \\
\hline
\end{tabular}

\section{The construction of a mathematical model of bolted} connection

We calculated the dependencies of the considered types of bolted connection in compliance with the previous study [11]. Tightening the bolt fixture results in tensile stress of the force $\mathrm{F}_{\text {pr. }}$ in the bolt shank and torsional forces from screwing $T_{K}$ (Fig. 1). The force of shear and the reaction in the support along the $\mathrm{x}$-axis $(\mathrm{Rx} 1, \mathrm{Rx} 2)$ in this system are considered as equal ones (Fig. 4). Therefore, increasing the force $\mathrm{F}$ leads to the increase of the reaction in the supports before it exceeds the static friction force in the bolted fixture, and, consequently, the shear happens.

The static friction force on each side is calculated by the following formula:

$$
\mathrm{F}^{*}=\mathrm{R}_{\mathrm{x}}=\mathrm{F}_{\mathrm{pr}} \cdot \mathrm{f}_{0} \cdot \mathrm{i}=400 \mathrm{~N},
$$

where $\mathrm{f}_{0}$ is the coefficient of friction in the joint parts, $i$ is the number of joints.

Thus, the shear is possible when the force in the supports (Rx1, Rx2) exceeds $400 \mathrm{~N}$. Hence, the reactions in the supports of the Rz1 and Rz2 directions are respectively equivalent to the force $\mathrm{F}$ distributed on the plates.

The first approximation for the assessment of the SSS applies geometrically nonlinear correlations of the associated bending and rods strain. In the case of large bends, the plates are assumed to be loaded with transverse load.

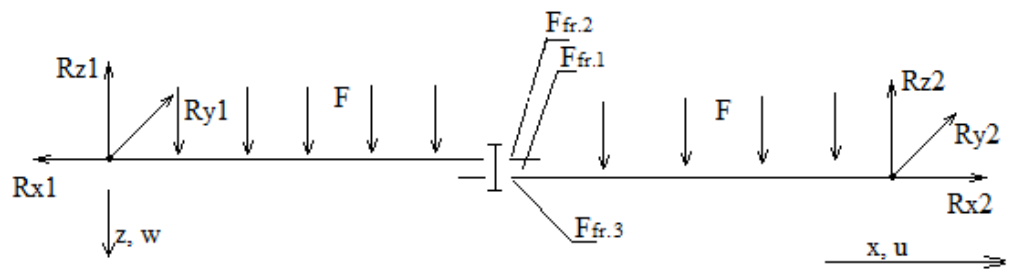

Fig. 4. Computation scheme of the bending rod
The equation that describes the bending of the rod is solved as follows:

$$
\mathrm{EIw}^{\mathrm{IV}}+\mathrm{Pw} \mathrm{w}^{\mathrm{II}}=\mathrm{q},
$$

where $\mathrm{q}$ is specific transverse load created by force $\mathrm{F}$, $\mathrm{P}=\int \mathrm{E} \varepsilon_{\mathrm{x}} \mathrm{ds}$ is tensile force-compression in the cross section of the rod, $w$ is the flexure of the rod, $\mathrm{E}$ is the flexural rigidity of the rod, and $\varepsilon_{\mathrm{x}}$ is deformation. Deformations in bending $\varepsilon_{\mathrm{x}}$ are calculated due to the following ratio [12, 13]:

$$
\varepsilon_{x}=\frac{\partial u}{\partial x}-z \frac{\partial^{2} w}{\partial x^{2}}+\frac{1}{2}\left(\frac{\partial w}{\partial x}\right)^{2}
$$

where $\mathrm{z}$ is the thickness distance from the median line of the rod, $\mathrm{u}, \mathrm{w}$ are components of the rod points displacement along the $\mathrm{x}$-axis and $\mathrm{z}$-axis respectively. Boundary conditions are: $\mathrm{u}(0)=\mathrm{u}(\mathrm{l})=0, \mathrm{w}(0)=\mathrm{w}^{\mathrm{I}}(0)=0$, and $\mathrm{w}(\mathrm{l})=\mathrm{w}^{\mathrm{I}}(\mathrm{l})=0$. Furthermore, the following conditions can be observed:

$$
\mathrm{u}_{\mathrm{Lf}}^{\mathrm{B}}-\mathrm{u}_{\mathrm{Lf}}^{\mathrm{R}} \geq \delta, \mathrm{u}_{\mathrm{R}}^{\mathrm{R}}-\mathrm{u}_{\mathrm{R}}^{\mathrm{B}} \geq \delta,
$$

which means non-penetration of the left contacting edge (due to the displacement along the $\mathrm{x}$-axis) to the left part of the bolt shank (the same is true for the right part).

This correlations define geometrically non-linear behavior of the system in terms of spatial performance. Structural nonlinearity (contact) and additional connection with the preload (bolt) and friction are also included as the supplementary items.

\section{A discrete formulation of the problem}

The numerical analysis of the studied problem is reduced to the finite element model shown in Fig. 5. The study applies the decomposition method to the finite mesh element "Sweep". The number of elements in the model is about 44 thousand, whereas the number of connection joints is 215.5 thousand.

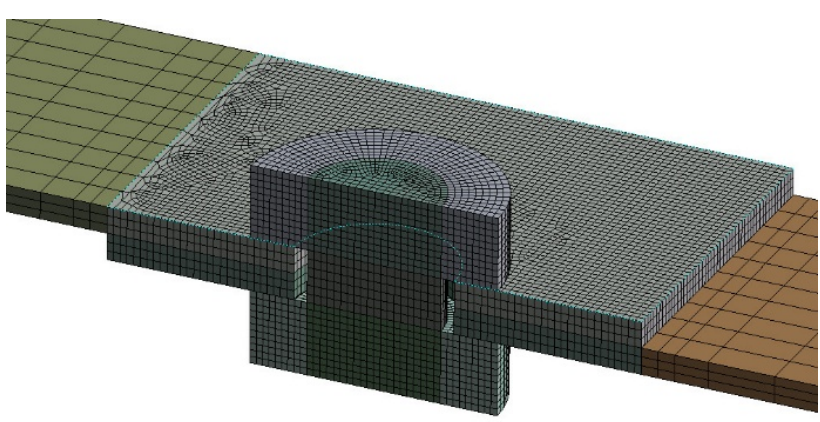

Fig. 5. The finite mesh element in the analyzed system of plates

The finite element of the SOLID classification-SOLID 186 is applied for this decomposition. It represents a three-dimensional (3D) quadratic task element with twenty connection joints. The SOLID 186 element has a quadratic representation of displacements and is able to use the irregular shape of the mesh (e.g. based on models imported from different CAD) 
$[14,15]$. When defining contact interactions, contact was set up symmetrically and its statement was determined by the augmented Lagrangian method. The solver settings used the command of large displacement since it allows considering large displacements that depend on the strains and stresses arising from the loading of the plates system.

The adequacy and accuracy of the constructed model were proved by the numerical and experimental solution of the problems $[16,17]$. The permissible error is within the range of $3-8 \%$.

\section{The results of the calculations}

First of all there was considered a bolt fixture without a washer and with a coefficient of friction equal to 0.2 . Shears of the plates, with the derivation of the maximum von Mises equivalent stress arising in the contact of the bolt and the plate are shown in Fig. $6, a-d, 7, a-d$. The dependency of the maximum bending of the system from the load along the $\mathrm{z}$-axis was compared on the graph in Fig. 8, $a$. Graphs of the distribution of von Mises equivalents are shown in Fig. 8, $b$.

The plates displacement and the clearance adjustment in the bolted fixture are nonlinearly dependent that was defined as the result analysis. Nonlinear dependence of the shear value from the actual load on the $\mathrm{x}$-axis between the contacting surfaces is also presented. Maximum equivalent stresses in the system increase nonlinearly and depend on the load. For a more detailed analysis of the contacting plate surfaces shear, we considered the dependence of the plate displacements about each other along the x-axis (Fig. 8, c).

A stepwise shear of the plates relative to each other is shown on the graph. There is no shear in the initial loading. The stepwise shear of the plates relative to each other occurs when the load increases to $120 \mathrm{~N}$. It is accompanied by partial clearance adjustment. In case of further load increase (after the clearance adjustment), deformation of the contacting plates and the bolt results in a slight shear.

Comparison of reactions in the fixing points of plates is shown in Fig. 8, $e, f$. Longitudinal components of the reaction, in contrast to the cross ones, changed significantly nonlinearly.

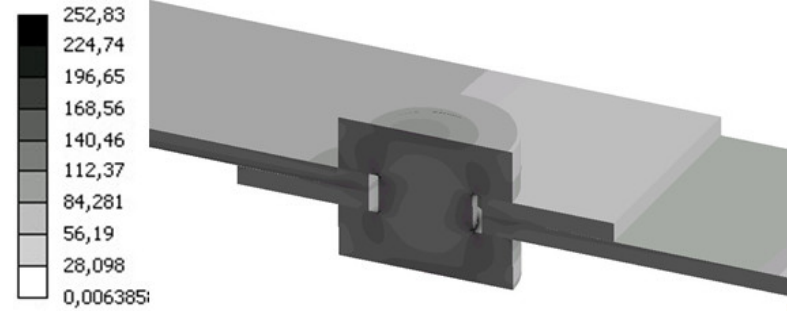

$a$
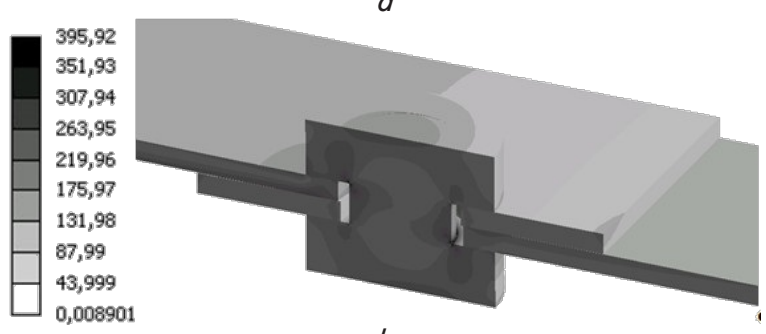

$b$
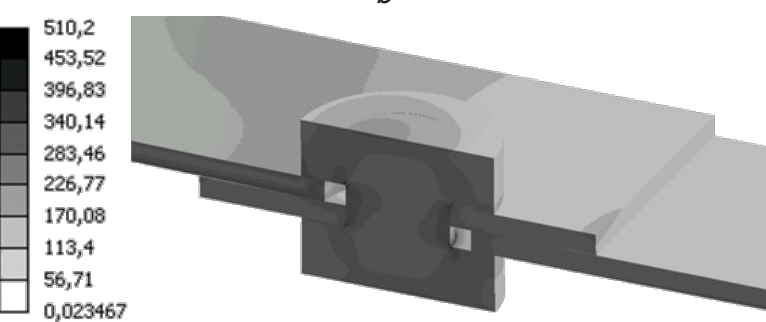

\begin{tabular}{|l}
1248,3 \\
1109,6 \\
970,89 \\
832,2 \\
693,5 \\
554,81 \\
416,12 \\
277,42 \\
138,73 \\
0,03632
\end{tabular}

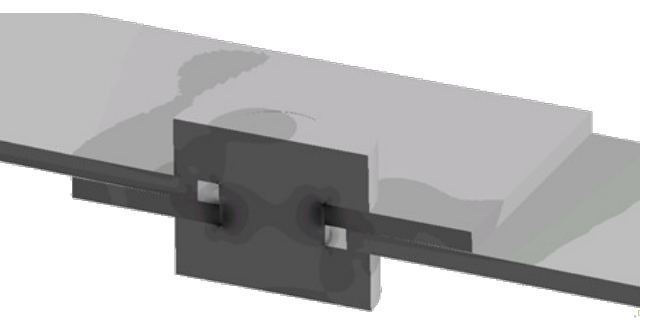

$d$

Fig. 7. The maximum von Mises equivalent stress (MPa): $a-$ the shear of plates is not observed; $b-$ the shear of plates is not observed; $c$ - the shear of plates and the clearance adjustment in the bolted connection are observed; $d$ - the clearance adjustment and the contact interaction of a bolt and the inner surface of the hole are observed
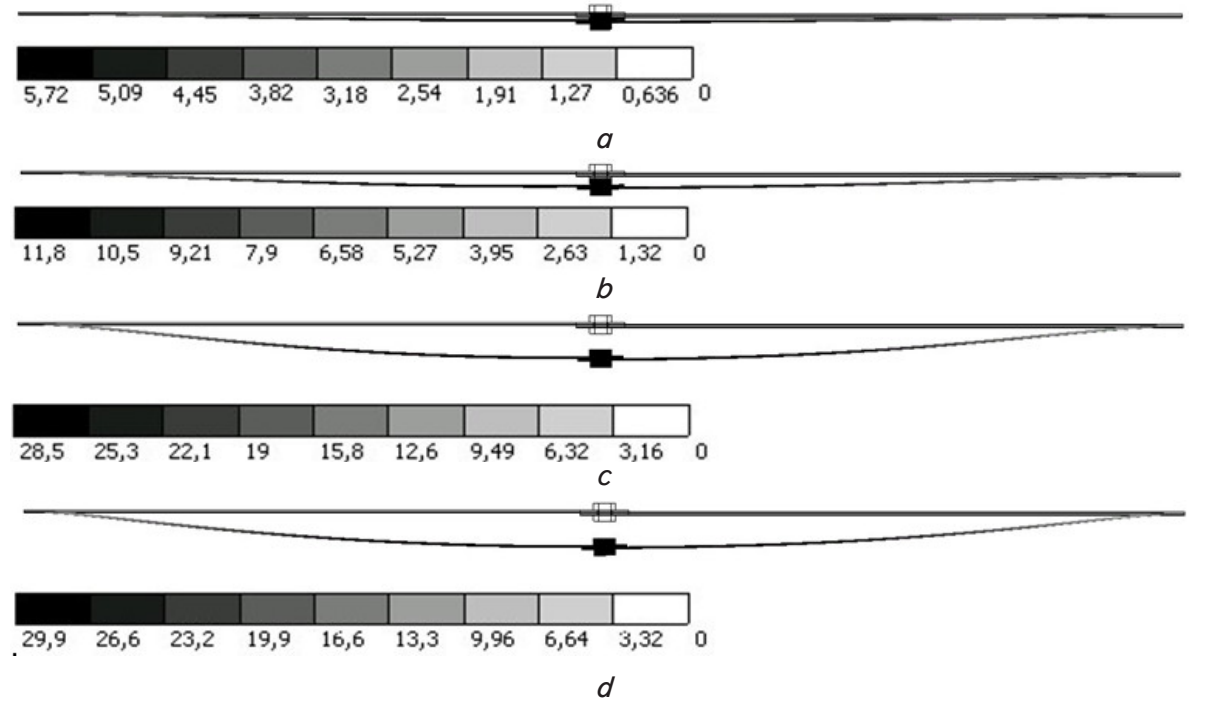

Fig. 6. Displacement along the z-axis $(\mathrm{mm}): a-$ at a force of $20 \mathrm{~N}$; $b-$ at a force of $70 \mathrm{~N} ; c-$ at a force of $180 \mathrm{~N} ; d-$ at a force of $450 \mathrm{~N}$
However, components of the reaction $\mathrm{Rx} 1$ increase approximately linearly with the increasing load associated with the contact. Therefore, causes of the nonlinear behavior for the reactions of the support components should be thoroughly considered. There is a shear during the loading of the plates. This is due to the loading force that exceeds the friction force in the connection. The increase of the loading force against the friction force is due to the bolt deformation arising from skewing. It thereby increases the force of the current bolt fixture tightening in comparison to its initial level. 

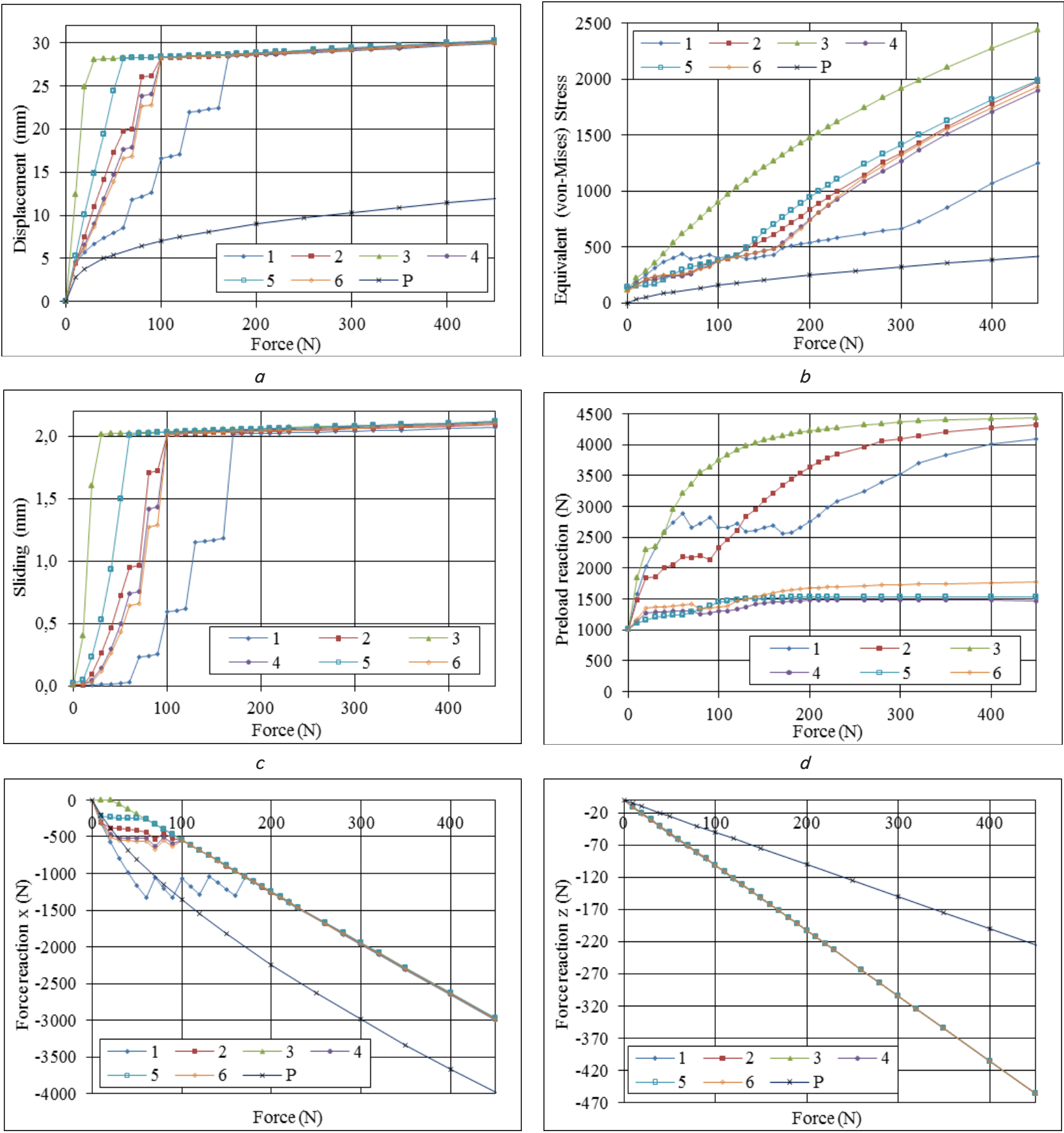

Fig. 8. The results of research (variants $1-6, \mathrm{P})$ : $a$ - displacement along the $z$-axis; $b$ - the maximum von Mises equivalent stress; $c$ - displacement of contacting plates surfaces in relation to each; $d$ - reactions in the bolt; $e-$ longitudinal reactions in the support Rx 1 under various configurations of the bolted connection; $f-$ cross reaction at the support Rz1

A reaction that occurs in the bolt should be analyzed in more detail (Fig. 8, $d$ ). The reaction begins to increase due to the bolt and plates deformation. There is a nonlinear increase that is accompanied by the increase in the tightening force of bolt fixtures. During the clearance adjustment the bolt surface begins to interact with the inner surface of the holes in the plates. Therefore, the bolt starts to work on the shear. Other configurations of the bolted connection are considered in order to eliminate this effect.
The displacement dependence of the plates system along the $\mathrm{z}$-axis, the maximum equivalent stresses, longitudinal reactions in the supports, as well as reactions arising in the bolt at various bolted connection configurations are shown in Fig. 8, $a-f$. The findings indicate that behavior types of the plate system vary depending on various bolted connections. When the contact of plates and the bolt cap using two compliant washers (variant 4) had a friction coefficient equal to 0.2 , the studied bolted connection provided an oppor- 
tunity to understand the cause of the increased reactions at the bolt. The higher is the rigidity of the connected parts the larger is the increase. However, there is no huge forces growth while introducing compliant elements into the system.

Geometrically nonlinear formulation for the system of plates and the conventional task solution, i. e. solid plate (variant $\mathrm{P}$ ), were compared with an account for the large displacements. Displacement along the $\mathrm{z}$-axis, the maximum von Mises equivalent stresses and reactions in the supports are shown in Fig. 8, $a-f$.

The study also contains a comparative analysis of a solid plate use and a plate with a bolt fixture (variant 1). The results of calculations show a large difference either between the displacement and the equivalent stress, or the reaction components at the supports. The behavior of a solid plate is displayed on charts more smoothly and linearly. However, the study proves that the system of plates is characterized by an essential nonlinear behavior. While the solid plate of displacement is loaded, the system of plates with a bolt fixture has more than twice less bends because of the structural nonlinearity in a system of bolted fixtures. Moreover, there are considerable gaps in comparison with the displacement values of plate points due to elastic deformations. The study of the combination of the design scheme of a solid plate, bolt fixtures, clearances, preloads and friction ensures accuracy of the obtained results.

\section{Conclusions}

1. The geometrically nonlinear formulation determining the SSS for plates with a bolted connection and a clearance in the fixture gives a more accurate result than the traditional calculated scheme of a solid plate. Maximum deformation of a solid plate is $0.012 \mathrm{~m}$, whereas plates with bolt fixtures and clearances show deformation of $0.028 \mathrm{~m}$. The equivalent (von-Mises) stress for a solid plate is $450 \mathrm{MPa}$, whereas for plates with a bolt fixture and a clearance it comprises $1200 \mathrm{MPa}$.

2. Additional factors affecting the SSS of the system include the bolt skewing and the plate deformation that lead to an increase of tensile forces in the bolt, thereby increasing the force of the bolt fixture tightening.

3. Large longitudinal and transverse displacements related to the clearance adjustment in the bolt fixture are comparable with the corresponding displacements observed in the solid plate due to its elastic deformation.

4. There is nonlinear shear with friction between the contacting surfaces of the plates during the system loading.

The proposed methodology can be used for solving similar tasks as it considers a wide range of operating loads. In case when the researched object is a solid plate, geometrically linear and non-linear formulations do not guarantee reliable results.

\section{References}

1. Atroshenko, O. O., Tretyakov, V. B., Ivantsov, I. I., Veretelnik, O. V. (). A rationale for calculation models of silo items [Text] / O. O. Atroshenko, V. B. Tretyakov, I. I. Ivantsov, O. V. Veretelnik // Vestnik NTU “KhPI”. - 2013. - Vol. 1. - P. 139-154.

2. Design of steel structures: Silos [Text]. - The European Committee for Standardization. Eurocode 3. Part 4. - Brussels, 2007.

3. Actions on Structures. General Actions - Snow Loads. Brussels, CEN [Text]: Eurocode 1. - Parts 1-3, 2003.

4. Actions on Structures. General Actions - Wind Actions. Brussels, CEN [Text]: Eurocode 1. - Parts 1-4, 2005.

5. Shi, Y. Analysis of Shear Behavior of High-Strength Bolts Connection [Text] / Y. Shi, M. Wang, Y. Wang // International Journal of Steel Structures. - 2011. - Vol. 11, Issue 2. - P. 203-213. doi: 10.1007/s13296-011-2008-0

6. Tang, G. Finite Element Analysis and Experimental Research on Mechanical Performance of Bolt Connections of Corrugated Steel Plates [Text] / G. Tang, L. Yin, X. Guo, J. Cui // International Journal of Steel Structures. - 2015. - Vol. 15, Issue 1. - P. 193-204. doi: 10.1007/s13296-015-3014-4

7. Gallego, E. A simplified analytical procedure for assessing the worst patch load location on circular steel silos with corrugated walls [Text] / E. Gallego, C. González-Montellano, A. Ramírez, F. Ayuga // Engineering Structures. - 2011. - Vol. 33, Issue 6. P. 1940-1954. doi: 10.1016/j.engstruct.2011.02.032

8. Mohammed, H. Fatigue Resistance of Corrugated Steel Sheets Bolted Lap Joints under Flexture [Text] / H. Mohammed, J. B. Kennedy // Practice Periodical on Structural Design and Construction. - 2009. - Vol. 14, Issue 4. - P. 242-245. doi: 10.1061/ (asce)sc.1943-5576.0000021

9. Chung, K. F. Finite element investigation on the structural behaviour of coldformed steel bolted connections [Text] / K. F. Chung, K. H. Ip // Engineering Structures. - 2001. - Vol. 23, Issue 9. - P. 1115-1125. doi: 10.1016/s0141-0296(01)00006-2

10. Ju, S.-H. Three-dimensional finite elements of steel bolted connections [Text] / S.-H. Ju, C.-Y. Fan, G. H. Wub // Engineering Structures. - 2004. - Vol. 26, Issue 3. - P. 403-413. doi: 10.1016/j.engstruct.2003.11.001

11. Anuriev, V. I. A handbook for designers and mechanical engineers [Text] / V. I. Anuriev. - Moscow: Mashinostroenie Publ., 2006. -928 p.

12. Vasidzu, K. Variation methods in the theory of elasticity and plasticity [Text] / K. Vasidzu. - Moscow: Mir Publ., 1987. - 542 p.

13. Birger, I. A. Strength of materials [Text] / I. A. Birger, R. R. Mavlyutov. - Moscow, Nauka Publ., 1986. - 560 p.

14. Basov, K. A. ANSYS: user's guide [Text] / K. A. Basov. - Moscow, DMK Press Publ., 2005. - 640 p.

15. Kaplun, A. B. ANSYS in the hands of engineers [Text] / A. B. Kaplun, Ye. M. Morozov, M. A. Olferyeva. - Moscow, Editorial Publ., 2003. $-272 \mathrm{p}$.

16. Atroshenko, A. A. Experimental research on the system of plates with a bolted connection [Text] / A. A. Atroshenko // Vestnik NTU "KhPI". - 2014. - Vol. 14. - P. 105-112.

17. Atroshenko, A. A. Bending of a plate with large displacements and longitudinal forces of influence [Text] / A. A. Atroshenko // Vestnik NTU "KhPI". - 2014. - Vol. 29. - P. 3-13. 